\title{
(Dis)connecting migration: transnationalism and nationalism beyond connectivity
}

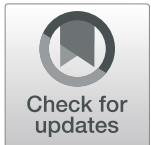

Magdalena Nowicka

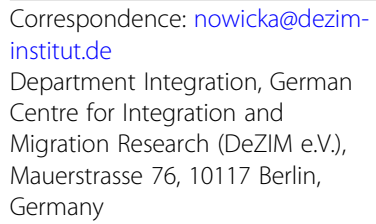

Correspondence: nowicka@deziminstitut.de

Department Integration, German Centre for Integration and Migration Research (DeZIM e.V.), Mauerstrasse 76, 10117 Berlin, Germany

\begin{abstract}
Transnationalism as a perspective that scrutinizes localities in more than one nationstate has helped to illuminate those aspects of lives of migrants that remain hidden when migration is seen through the lens of conventional migration theory. Social connectivity provides a context in which effects of migration can be studied. Yet reducing transnationalism to connectivity is unproductive for understanding currentday sociality as possibly distinct from a national one. This paper proposes to consider how nationalism is embedded in migrants' 'deep stories', and how these stories are altered in migration. It exemplarily analyses narrations from interviews with Polish migrants in England. The paper argues that connectivity and social context are equally important for transnationalism, but transnationalism cannot be reduced either to one or the other. In turn, we must define transnationalism as outcome of multiple belongings, practise and dispositions coming together.

Keywords: Transnationalism, Nationalism, Migration, Polish migrants, England, Deep stories, Connectivity
\end{abstract}

\section{Introduction}

The emergence of transnationalism in international migration studies goes back to the late 1980s and early 1990s and the seminal works of Massey (Durand and Massey 1992; Massey and España 1987; Massey et al. 1994), Basch et al. (1993), Portes (1995), Smith and Guarnizo (1998), and their colleagues. While has long been known that international migrants maintain close ties to their nearest and dearest 'left behind' (Foner 2000; Thomas and Znaniecki 1984 [1918-1920]), only with the new transnational field of studies have these connections become the main focus of interest for numerous researchers. Migrants' ties across the borders of nation-states, as many scholars have argued, are meaningful for their effects on the politics, economies and societies in both countries, and migrants themselves. A vast number of empirical studies have since then demonstrated the existence, in various forms and with great intensity, of such connections and their practical and theoretical significance (Portes et al. 1999). The focus on border-crossing activities has helped to illuminate those aspects of lives of migrants that remain hidden when migration is seen through the lens of conventional migration theory.

(c) The Author(s). 2020 Open Access This article is licensed under a Creative Commons Attribution 4.0 International License, which permits use, sharing, adaptation, distribution and reproduction in any medium or format, as long as you give appropriate credit to the original author(s) and the source, provide a link to the Creative Commons licence, and indicate if changes were made. The images or other third party material in this article are included in the article's Creative Commons licence, unless indicated otherwise in a credit line to the material. If material is not included in the article's Creative Commons licence and your intended use is not permitted by statutory regulation or exceeds the permitted use, you will need to obtain permission directly from the copyright holder. To view a copy of this licence, visit http://creativecommons.org/licenses/by/4.0/. 
As a distinctive perspective on migration, transnationalism is continuously criticized for lack of analytical stringency, theoretical imprecision, definitory confusion with other concepts, and insufficient involvement of general social theory, just to name a few of the most general allegations. Obviously, the 'transnationalists' themselves also call regularly for a theoretical and methodological renewal of transnational studies (i.a. Wimmer and Glick Schiller 2002; Levitt and Jaworksy 2007; Amelina 2010; Boccagni 2012; Levitt and La Dehesa 2017). The usual 'dos' and 'don'ts' of transnationalism always include avoiding methodological nationalism. Out of the multiple lines of critique, I want to focus on just one, formulated prominently by Waldinger (2015): it is the reduction of transnationalism to connectivity. In this paper, I follow Waldinger's line of argumentation up to a certain point and bring then nationalism into discussion to finally propose a definition of transnationalism which goes beyond connectivity. Thereby, I also follow Appadurai's (1996, p. 185) call to embed transnationalism in the contingencies of history.

I illustrate my argument with examples from my own research. I show how nationalism shapes the schemes of remembering and forgetting, and the way they think of their present and imagine their future. Also, nationalism permeates into the structures of feeling (Bonikowski 2016). I draw on the notion of 'deep story' proposed by the anthropologist Hochschild (2016) to address the entanglements of personal and collective national histories, and the feelings attached to them. As a scholar of migration, I am interested in what happens to such 'deep stories' when people migrate internationally and stay connected to their places of origin. In section five, thus, I discuss examples of narratives of Poles living in England that I have collected over the past years to demonstrate how migrants negotiate the meaning of past and current events in their lives when confronted with new and unfamiliar cultural schemes, and how their attitudes might shift over the course of migration. Yet, I also argue that the 'deep stories' remain a stable point of reference for migrants in how they feel about what is fair and just and what is not, and how to behave accordingly.

I argue that understanding migrants' 'deep stories' must have consequences for how we conceptualise transnationalism as the outcome of encounters in migration. The vast literature on transnationalism focusing on individuals stressed the transformations of their identities in migration; another string of research looked at transforming powers of nation-states, and yet another addressed the transformations of localities due to mobilities. My concern here is not the effects on individuals, states or localities, but on how we understand transnationalism. I argue that connectivity and social context are equally important for transnationalism, but transnationalism cannot be reduced either to one or the other. This take on transnationalism allows addressing the aspirations of migrants and their attitudes, and apparent paradoxes in their behaviour, as well as tensions that may emerge between long-term residents and newcomers from other countries.

\section{Transnational migration and connectivity}

Recently, Waldinger (2015) criticized 'transnational' scholars' pre-occupation with connectivity. He argues that connectivity is immanent to every form of international migration; in this sense, connectivity must be a null hypothesis of migration studies. Second, this connectivity leads to even more connectivity, in the form of businesses serving 
migrants, travel routes, exchange of goods, transfers of money, etc. Thus, and third, connectivity is a source and effect of international migration, which often leads to an analytical confusion. The challenge, in Waldinger's view inadequately addressed, is to understand the variance in these connections (why some linkages persist, attenuate, or fade away; what different patterns can be observed) instead of proving their existence (Waldinger 2015, p. 6).

Waldinger (2015, p. 32) argues that these problems troubling transnational scholarship are linked to conflating 'state' and 'nation', the first referring to territorial units, the second to social collectivities. Accordingly, migration is crossing of borders of territorial units; if it also means emergence of new collectivities is subject to empirical investigation and cannot be assumed a priori. A similar argument was formulated earlier by Bommes (2003, p. 103) who reminded us that international migration is archetypical to the emergence and consolidation of nation-states, and warned transnational scholars not to simply replace the concept of society with that of a transnational social space. This conflation, so Waldinger (2015, p. 32), results in (and this is the fourth problem of transnationalism) mistaking connectivity with collectivity. Having ties to people elsewhere does not necessarily lead to more solidarity or advance ethical concern and action towards those who 'stayed behind' that is a basis for community, and vice-versa. Waldinger (2015, pp. 33-34) calls thus to carefully scrutinize the form, duration and context of social ties, and identify how these differ if they span within or across nationstates.

Waldinger (2015) is one of the most prominent critics of transnationalism, but similar arguments were raised by other scholars as well. For example, Carling (2014) urges us to distinguish between the existing connections (for example, having a relative abroad), transactions (exchanging with this relative) and scripts (norms governing these transactions). Without transactions, connections would not survive. Bommes (2003, p. 106) is critical of mistaking the sheer existence of connections for the emergence of transnationalism as a form of collectivity.

In a similar vein, authors unengaged in the debates on transnationalism are sceptical of the usefulness of the concept of connectivity. By seeing the world as nodes connected by ties, we miss attending to the social context: the pre-existing knowledge and discourses external to people that have significant effects on their lives. The world viewed through the lens of connectivity emerges as atomised and individuated; it suggests some kind of equal positions of nodes and thus produces a 'flat topography' (Erickson 2012, p. 918). Coward (2018) admonishes us for prioritising connectivity in thinking of the social: such a focus goes hand in hand with lack of concern for contiguity and context. In turn, social science fails to adequately attend to culture and collectivity. Similarly, Holton (2005) reminds us that connectivity is a product of culture and collectivity.

\section{Transnational migration and nation-states}

Here is where the nation-state enters the debate again. Conventional migration studies focused on the post-arrival lives of migrants. In this view, migrants 'bring their culture with them' (Erel 2010) and with the time become more or less assimilated to the norms of the new place of residence. The 'receiving country bias' (Castles 2010, p. 1571) inherent to these studies has considered primarily the situation of migrants in (northern) 
destination countries, neglecting the perspectives of origin and transit countries. In turn, it missed acknowledging that migrants' pasts cannot be assimilated, and thus failed to adequately analyse the sources of tensions and frustrations that migrants (and non-migrants) experience after migration. Transnational scholarship treats the lives of migrants in their pre- and post-migration phases as equally important. By grounding transnationalism in localities, transnational scholars produced good accounts of how local contexts impact transnational ties, and how transnational (or global) ties impact localities (Portes et al. 1999; Smith and Guarnizo 1998), and thus put light on the complex processes of glocalization (Robertson 1995). However, as Waldinger critically notices, the majority of studies on migrants' connections produced good accounts of bilocalism across nation-states borders but not of transnationalism (Waldinger 2015, p. 34), for local and national involvements and loyalties cannot be thought as synonymous. Thus, transnationalism needs to address the workings of nationalism, while avoiding the trap of treating nation-states (and nationalism) as de facto containers and overlooking the porosity of territorial borders (Mitchell 1997, p. 105).

The transnational scholarship's relation to nationalism remains surprisingly vague, though. Transnational scholarship emphasized the need of overcoming the unreflective use of the nation-state as an appropriate scale for empirical investigation - the latent methodological nationalism of conventional migration scholarship (Amelina et al. 2012; Faist 2012; Wimmer and Glick Schiller 2002). It this respect it provided useful impulses. As Hannerz (1996) noticed, transnationalism entails in the name what it negates - the national - and thus also the continued significance of nation-states. States are prominent in multiple ways: as actors of economic globalisation, producers of homogenizing and bounding discourses on (local) communities, and agents regulating migration flows. Citizenship rights and their denial to certain groups of people (Bloemraad 2004; Ehrkamp and Leitner 2006; Levitt and La Dehesa 2017) as well as territorial border politics (Nieswand 2018) is the key instrument of power of nation-states. As Levitt and Glick Schiller (2004) reminded, migrants are simultaneously exposed to regulatory hegemonic powers of more than one nation-state and their exclusionary discourses. They are embedded in multiple legal and political institutions that determine their access to rights and legitimate gender, race and class status.

Yet to thematise the regulative powers of nation-states is not the same as engaging with relevance of nationalism. It is not my aim to pin down the exact causes of why transnationalism hardly ever draws upon the main theories of nationalism. These debates seem rather foregrounded in the field of diaspora studies (Bauböck and Faist 2010), albeit the concepts of 'transnational nationalism' (Kastoryano 2006) or 'long distance nationalism' (Anderson 1998) both highlight various forms of political engagement of migrants in countries of their origin that is rooted in people's belief in a nation (Glick Schiller 2005). Yet the voices of those who do not engage in economic or political transactions across nation-state borders might easily get overlooked by transnational scholarship if the last focuses connectivity. Possibly, transnationalism's aversion to bounded entities, fear of cultural essentialism, as well as demarcating from diaspora studies with their interest in bounded cultural identities (Glick Schiller 2006), as well as interest in cosmopolitan identities that reach beyond local or national attachments (Roudometof 2005) has produced a tendency to treat transnationalism as opposite of nationalism, or at least to neglect the meaning of nationalism. 
Thereby it is important to differentiate between the nation-state as a form of political organisation and institutional configuration, and nationalism as an everyday structure of thinking and feeling, which is not the same as a conscious ideology (Billig 1995; Brubaker 1996; Calhoun 1997). Various authors have pointed towards how the nation and nationstate is naturalised and perpetuated on a daily basis through consumption of media content, the prominence of national figures in street-naming practices, the displays of museums, administrative statistics, cartography, school curricula, and multiple other symbolic reminders of a constructed common national past (for overview see Bonikowski 2016).

Obviously, nationalism does not affect all people in the same way. Its effects are likely to be mediated by social class, religiosity, age, gender and cohort, and can resonate with economic insecurity and racial resentments. In turn, 'nation' is not an abstract concept, but it has different meanings to people (Bonikowski 2016). Nationalism is a part of a cultural repertoire (Lamont 1992), and potentially bridges across different social groups. It is because regardless of one's position (as worker, student, or retiree, man or woman), people are exposed to the same national symbols and narratives, albeit they may situate themselves differently to them. For example, a Polish university professor trained in the humanities and sympathising with leftist parties might be critical of the January insurrection (1863) against the Russian rule in Poland for it was badly prepared, damned to be unsuccessful and cost many human lives; for a young man drawn to the new nationalist right movements, the same event might be the starting date of Polish independence, glorified by nationalists since 1918 onwards (Burant 1985). And while certainly a large number of Poles could not give any details about this or other uprisings, at least they have heard of them at school, and they have a sense that Poles are a nation of courageous (or risk-loving) men who dedicate their lives if the situation requires it. Every country has such histories and their heroes and heroines which are hard for other nationals to comprehend.

Nationalism also shapes how events that are not particular to one country are remembered (or forgotten). A good example is how the Holocaust is embedded in national schemes of remembering and forgetting. The 'Jedwabne' case - the massacre of the Jewish inhabitants of Jedwabne by their Polish neighbours - a crime silenced for about 60 years, fits into a larger culture of forgetting the Jewish presence in the territory of what is now Poland (Plonowska Ziarek 2007) and signifies a deeper antisemitism which is detectable in public opinion surveys and the daily life of people in Poland (Bulska and Winiewski 2018). It fits into the victimhood-based national identity (Bilewicz et al. 2012). The same kind of forgetting seems impossible just across the Polish western border, in Germany, where the Holocaust is a significant moral principle (Krieg 2015). The strength of the nationalism does not mean that memories are not becoming detached from their local contexts and transnationalized (Levy and Sznaider 2002). Some symbols pervade and speak to all. Just like the apple, the cross, and the snake are readable to atheists and believers alike if they grew up in a Christian country, so are some events a part of a cultural repertoire of people, but the feelings they assign to them differ along their personal, local and national histories.

\section{Deep (national) stories}

Nationalism(s) are not only a structure of thought but permeate into the structures of feeling. To better capture how people feel about a situation which is not necessarily a 
subject of public debates, but which nevertheless penetrates into one's consciousness, Hochschild (2016) proposed the term 'deep story'. 'Deep stories' provide a moral and emotional compass to people, giving them the sense that what they think and feel is right and true. Such 'deep stories' lend a sense of fairness and justice and drive the way people think of something as really (objectively) existing, as a fact. In this sense they are more than a cultural repertoire, which is a relatively stable scheme of judgements that people use in varying proportions (Lamont 1992; Lamont and Fleming 2005). While 'cultural repertoires' refer to social norms and values of a particular group or society, the concept of 'deep stories' points instead to entanglements of personal (family) histories and (national) historical events. The personal (family) and historical (national) collective experiences are intertwined in a way which one lends sense to the other and vice-versa.

One example from my own studies among Polish migrants in England ${ }^{1}$ is a story of one young woman (let us call her Ania) I interviewed in London. Asked about her first impression upon arrival in England she mentioned her encounters with black peoples, and a rather troublesome relationship with her black neighbour. Ania followed it with a history from her childhood in Poland, when she was seriously injured in an accident and "a black doctor, an immigrant from Africa", saved her life. Thereafter, she argued to us, her father taught her to have no prejudice towards blacks (Nowicka 2018a). Ania's story reflects two historical events. In the 1960s more than 500 students from 23 African countries (mainly from Sudan, Mali, Nigeria, Ethiopia, Ghana, Congo and Morocco) studied at Polish universities, most of them in medicine, technology and economics. In early the 1970s scientific exchange between Poland and various African countries intensified, and some of the graduates from Polish universities settled successfully in Poland (Codogni 2010). While educational migration from Africa was not restricted to communist Poland (similar programmes existed in other countries), encounters with black medical doctors, a national experience in an otherwise ethnically and racially homogenous country, is a part of the Polish collective and has shaped Poles' attitudes towards blacks (Ząbek 2007). Second, Ania's story reflects Poles' attitudes towards Africans and blacks. The number of Africans in Poland, when Ania was a child as well as now, is extremely small, and Poles show a great social distance towards this group (Danecka and Jaroszewska 2013). Ania stressed her attitude is different because of the injury and the help she received from a black doctor. Both the scarce presence of Africans in Poland, and the general racism towards blacks in Poland make Ania's story exceptional. The successful treatment of the injury by an African doctor are for Ania a moral compass. By not discriminating against blacks, she feels she is doing right; she is and will be always 'thankful' to this particular doctor for saving her life, which she expresses with her commitment to treat all blacks with respect.

\footnotetext{
${ }^{1}$ The first study encompassed in-depth interviews with 25 migrants from Poland in London, and 19 in various towns in the Midlands, all conducted between November 2010 and August 2011. The second project TRANSFORmIG was located in London and Birmingham; in each city, the project team conducted interviews with 31 Polish migrants, whom we met three times, in spring 2014 and a year and 2 years after. Despite some differences in the interview scripts, both projects prompted accounts of informants' everyday practices, and their opinions of and encounters with people of different skin colours, ethnicities, national backgrounds and religions than their own.
} 


\section{'Deep stories' and migration}

What happens to such 'deep stories' when people migrate internationally? Piore (1979) has argued that migrants are 'social outsiders', evaluating conditions here (in the country of immigration) in light of standards there (the country of origin) (also Nowicka 2014a). From the phenomenological viewpoint, 'orientation' is a natural standpoint from which the world unfolds, becomes real and more or less familiar (Ahmed 2006). A 'double orientation' is accordingly two standpoints from which the same world unfolds, and an object appears as given to us. But what if these standpoints are different, for one is rooted in one social space, and the other in another? How do these different backgrounds allow what comes into view and how (Ahmed 2006, p. 547)?

When Ania told us about her friendship with people from different countries she used the label 'blacks' ("czarni" in the original). But when she spoke about her neighbour, she called him suddenly "a stupid Negro" ("głupi Murzyn"), falling into the Polish 'cultural repertoire' when talking to another Pole (interviewer). His flat was a mess and was "too lazy to get a job", a typical black. When she noticed that her words could be read as racist in the context of an interview taking place in London, she changed the course of the conversation. From her new standpoint - Ania's life in London - she quickly assigned the fault of their quarrels to him alone, for his rather "difficult character". She individualised the case, made it exceptional and thus not allowing judgement of all blacks, for her other encounters with blacks were positive and friendly. She also clearly positioned herself as a tolerant person, recalling the story from her childhood and gratitude to the black surgeon who saved her life. But in the London context, this 'injury history' gains a new character. It is no longer just a dramatic history of a serious accident in childhood, but it now matters that the doctor was black and that her father since that dramatic event was committed to antiracism, a stance which she inherited from him and which allows her convivial cohabitation with many people in London. In many interviews with Poles in England the use of 'blacks' and 'Negros' simultaneously is rather common; the first appears mostly in reference to events in England, the second when interviewees recall events that had taken place in Poland (Nowicka 2018a). This nicely illustrates the "double orientation" of Poles who draw on the vocabulary (and social norms that stand behind them) newly acquired in England but also employ cultural schemes rooted in the kind of Polish nationalism which excludes non-white and non-Christian others from its community.

Most of the 'deep stories' of migrants we interviewed relate, however, not to a multicultural society but to work ethics. Various authors could demonstrate that many Poles in Britain present themselves as makers of their own professional career who embrace the individualistic market-oriented values (Eade 2007). They present themselves as good migrants and good workers (Nowicka 2014a, 2018b); they thereby construct their own capability to work hard as an ethnic feature (Datta and Brickell 2009). Narrating about themselves and other migrants in Britain, these migrants disidentify from those 'bad' migrants who lack English language proficiency, socialise exclusively within their own ethnic group, misuse the welfare state, and make no efforts to get a job.

Many of the individual narrations I collected in England since 2010 include family histories of dedication, suffering and enduring. Emil, as I call him, was grateful for his parent's dedication that enabled him to complete a degree in the faculty of law of a university in a major Polish city. He explained that his parents were "strivers"; they were 
born in a small provincial town but moved away from their families to take better paying jobs in a larger town. They worked hard and long hours, so his grandmother took care of him. Thanks to his parent's financial support, he could focus entirely on learning. When studying he did not need to work in a bar or elsewhere to earn his own living. This sacrifice paid off: he graduated from the university and immediately got a well-paid job in a large company. He was responsible for legal aspects of procurement, was promoted quickly, and his parents were very proud of him. Yet he soon discovered foul deeds behind the scenes at this company. He moved on to another company but had no luck there either. The job was disappointing and stressing to him, and he decided to quit and look for work in London instead. The pressure on him to achieve success as a lawyer was so heavy that he did not tell his parents about his plan; he only told them a day before the departure when he packed his largest suitcase and put it in the corridor of their common flat. He recalled:

"and then... yeah, they (my parents) were really offended... for about half a year they reproached me for this decision... what for did we invest in you, and so on, you lose it all (your position, your chances) when you move to London..."

Emil's first job in London was washing dishes in a restaurant, then he was promoted and finally supervised others. After a year, he moved to a catering company located in an office building hosting largest legal chancelleries and banking companies. He then moved to a reception desk in one of these companies, and finally to an executive office, where he did simple administrative services. At the time of the interview, he was working as an assistant to two lawyers.

While clearly performing jobs beneath his education and experience, Emil found a source of pride for himself and for his parents in working hard: "I worked like a dog! All day long, twelve hours, I had just one day off a week." When asked how his parents dealt with him as an educated lawyer working in a restaurant, he said:

"I don't know, really, perhaps with the time... when they saw it here (in London), and they could brag about me working now in this place..."

He and his parents also found pride in him managing to climb up the social ladder in London. Despite that, he is not working as a lawyer now; he might succeed in this profession 1 day, not in Poland but in London, which has some sort of higher value. For now, he mixes with lawyers and bankers, and can enjoy the view from his office on the top floor of a modern building in the middle of London City. In fact, Emil is following his parents' path: he is a 'striver' working hard for his success.

Emil's personal history is representative of many young Poles who grew up in the times of 'turbo capitalism' in Poland (Hardy 2009) whose parents pushed them to higher education degrees and well-paid jobs. At this time, foreign companies invested in Poland, and the post-communist generation grew up to become accountable, responsible, self-managing and self-regulating subjects (Dunn 2004). Many of them were the first in their families to achieve a university degree, and many moved to larger cities to find better-paid and more prestigious jobs in foreign companies. Their ambitions were often disappointed (Nowicka 2014a) which made them migrate to Britain where they 
yet tend to work in manual and badly paid jobs. Their work ethos, and their drive for upward mobility, allows them to distinguish themselves as 'model migrants' from those 'lazy, immoral' others. They ethicise their work ethos, assigning it as essential quality of Poles.

This 'deep story' is so strong that many of them are supportive of austerity measures and cuts in unemployment and other social benefits, even if they would be the ones profiting from them. The main argument they give for less state support is that benefits are demotivating, which leads to a growing gap between those who work (hard) and those who 'do nothing'. As one participant in the online focus group I conducted in November 2018 among Polish migrants in London ${ }^{2}$ wrote:

"I feel it is unjust. As far as I know if you have two jobs you automatically pay a higher tax no matter how much you earn but otherwise, they pay people who do nothing."

Some participants resolutely reject the need for state support yet count themselves as deserving of it. "I have a job and don't need the government's help", one said, and another person stressed:

"I don't personally know such people [on benefits], my friends here buy houses and run businesses and send their children to good schools".

At the same time, these migrants become critical of their own socialisation. Some of the research participants were explicitly negative about the neoliberal pressures in Poland. One noted:

"Simply speaking, in Poland we still feel the need to demonstrate and stress our status with the help of goods. A good car, a huge house, etc. Here I mean this is less the case".

Someone else added:

"due to the years of a shortage of everything in Poland, some attempt to make up for it now, plus there's a Slavic, not just Polish, need to keep up with the Joneses."

They were equally critical of how employers in Poland require all staff to hold a higher education diploma, and of "wild capitalism and abuses", as another person wrote.

What lurks throughout these narratives is a mixture of personal histories of struggle for success and the power of the nation (welfare) state to determine the course of people's (migrants') life, as well as their thinking of their own and others' entitlements, ambitions and actual positions. Migrants positioned between two national systems may

\footnotetext{
${ }^{2}$ This study included online focus group interviews (FGIs) with Poles living in London and Birmingham that took place in March 2017, with 12 Poles in London and nine in Birmingham, as well in November 2018, with nine Poles in London and eight in Birmingham. The FGIs targeted their perceptions of life in England after the Brexit vote. The participants in online FGIs logged in to a secure chat room; the discussion was moderated and was similar to a traditional face-to-face focus group. Each of the discussions lasted approximately $2 \mathrm{~h}$. The data generated is a mixture of self-talk and public discourse (Nowicka 2020).
} 
combine two logics, each shaped by the particular historical conditions. However, migration also means for them a confrontation with a new, unfamiliar context, and migrants struggle to make their 'deep stories' fit this new environment. Their personal histories, the events that have shaped their family and their own trajectories, may be re-interpreted, gaining new meaning. But the 'deep story' remains the same - of a hard-working person capable of upward social mobility in Poland, or in Britain. The fit that they achieve, paradoxically, is with the part of the population which is most antiimmigrant and in support of measures hurting the most vulnerable migrants.

\section{Transnationalism disconnected}

Of course, these processes of re-interpreting personal trajectories and their meanings proceeds within social networks, and some parts of these networks stretch beyond the border of one nation-state. Interactions with direct work colleagues, neighbours, and friends in Britain are important for Polish migrants learning new skills and competences to operate in an 'urban multiculture' (Back 1996). For example, my research shows that people whose networks are less ethnically homogenous are less socially distanced from people of different races, religions or nationalities (Nowicka and Krzyżowski 2017). Migrants' interactions with their nearest and dearest in their place of origin are important, as these people also constitute their 'point of reference': doing well, or doing better, being successful or failing is defined in reference to these people (Nowicka 2014b). These are network effects, which need to be differentiated from migration effects - the effects of people changing their place of residence internationally.

Social connectivity thus provides a context in which effects of migration can be studied (Fouron and Schiller 2001). In the process of people migrating and establishing connections across borders, the culturally specific and taken-for-granted local norms and values move, circulate and interact with other culturally specific local norms and values, a condition which Tsing (2005) terms 'friction'. Friction means resistance that one surface or object encounters when moving over another, rubbing. It can also mean conflict or animosity caused by a clash of wills, temperaments or opinions. For Tsing, friction is essential, as it enables movement. She gives an example of a car which moves when its wheels meet the road: rotation creates movement, like rubbing two sticks together produces heat and light (Tsing 2005, p. 5). To take this metaphor even further, we can consider the effects of friction on the materials involved in the encounter: the tyre and the asphalt alter during the encounter, but also beyond it - the tyre heats and rubs off, particles are set free, leading to increased air pollution, etc. Through regular encounters, abrasion is observable. Its extent depends on the quality of roads, etc. The metaphor of 'friction' helps us thus to think of the meaning of encounters that happen when people change their place of residence between countries. In migration, a new condition emerges, a productive space in-between, where migrants engage with old and new ideas and practices. Focusing on this condition means for us to study multiple, emergent and competing norms, values, attitudes and practices. Transnationalism as I understand it is the outcome of multiple belongings, practices and dispositions coming together.

In this definition of transnationalism, connectivity (including personal social networks of migrants, some of them spanning the borders of nation states) is important insofar as it enables encounters, and in turn transnationalism. Not every encounter, however, 
necessarily leads to transnationalism. Let me return to the metaphor of friction. Friction - tension, resistance - depends on the qualities of the materials that come together. Thus, social contexts, shaped by nationalism, local socio-economic conditions, universal values, as well as family histories, are essential for transnationalism as well. Thus, the merit of a transnational lens is to make us attentive to what remains constant. Unlike the concept of hybridity, which allows to see the emergence of a new, third 'species' in the contact zone of two cultures, transnationalism exposes the continuities, the fractious, unruly, recusant, intractable outcomes of (national) socializations, everything that feels true and right by virtue of being familiar and deeply situated. Thereby, it avoids seeing nationalism as a source of evil, despite the obvious co-existence of national rhetoric, antisemitism, and racism in right-wing populism. Being sensitive to nationalism and its workings, transnationalism remains, as it always has been in fact, cautious of conceptualising societies and cultures as bounded. Through the focus of the entanglements of national and personal histories of migrants, transnationalism also avoids seeing identities and belongings in terms of ethnicity; instead, it attempts to understand what happens before categorical (self-) attribution of difference to particular groups.

This seems an important contribution transnational scholarship can make in the times of right-wing populism spreading (and connecting across borders!) in Europe, and growing nativism, racial prejudice and xenophobia. Transnational perspective counters the unproductive view that migrants' prevailing racial, homophobic or Islamophobic attitudes is a result of embeddedness in the context of their country of origin and in terms of their insufficient assimilation in new country. Yet if reduced to connectivity, transnationalism also is in danger to reinforcing assimilationist thinking for, as Werbner (2015) warned us, identities are not always subject to fusion; they often tend to resist hybridisation. Instead, we need such a definition of transnationalism that helps us to interrogate the interplay of connectivity and social embeddedness which underlies the current situation.

Acknowledgements

N.A.

Authors' contributions

The author(s) read and approved the final manuscript.

Funding

This work was supported by European Research Council [ERC Starting Grant 313369 awarded to Prof. Magdalena Nowicka].

Availability of data and materials

N.A.

Competing interests

The authors declare that they have no competing interests.

Received: 31 May 2019 Accepted: 13 March 2020

Published online: 15 June 2020

References

Ahmed, S. (2006). Orientations: Toward a queer phenomenology. GLQ: A Journal of Lesbian and Gay Studies, 12(4), $543-574$.

Amelina, A. (2010). Searching for an Appropriate Research Strategy on Transnational Migration: The Logic of Multi-Sited

Research and the Advantage of the Cultural Interferences Approach. Forum: Qualitative Sozialforschung/Forum: Qualitative Social Research, 11(1). http://www.qualitative-research.net/index.php/fqs/article/view/1279. Accessed 17 Mar 2020.

Amelina, A., Nergiz, D. D., Faist, T., \& Glick Schiller, N. (Eds.) (2012). Routledge research in transnationalism. Beyond methodological nationalism: Social science research methods in transition. London: Routledge.

Anderson, B. (1998). The spectre of comparisons nationalism, Southeast Asia, and the world. London: Verso. 
Appadurai, A. (1996). Modernity at large: Cultural dimensions of globalization. Public worlds. Minneapolis: University of Minnesota Press.

Back, L. (1996). New ethnicities and urban culture: Social identity and racism in the lives of young people. London: Taylor and Francis.

Basch, L. G., Glick Schiller, N., \& Szanton Blanc, C. (1993). Nations unbound: Transnational projects, postcolonial predicaments, and deterritorialized nation-states. London: Routledge.

Bauböck, R., \& Faist, T. (Eds.) (2010). IMISCOE research. Diaspora and transnationalism: Concepts, theories and methods. Amsterdam: Amsterdam University Press.

Bilewicz, M., Winiewski, M., \& Radzik, Z. (2012). Antisemitism in Poland: Psychological, religious, and historical aspects. Journal for the Study of Antisemitism, 4(2), 423-443.

Billig, M. (1995). Banal nationalism. London: Sage.

Bloemraad, I. (2004). Who claims dual citizenship? The limits of postnationalism, the possibilities of transnationalism, and the persistence of traditional citizenship. International Migration Review, 38(2), 389-426.

Boccagni, P. (2012). Rethinking transnational studies. European Journal of Social Theory, 15(1), 117-132.

Bommes, M. (2003). Der Mythos des transnationalen Raumes:: Oder: Worin besteht die Herausforderung des Transnationalismus für die Migrationsforschung [The myth of transnational space. Or: what is the challange of transnationalism in migration research]? In D. Thränhardt, \& U. Hunger (Eds.), Migration im Spannungsfeld von Globalisierung und Nationalstaat [Migration between Globalisation and Nation State] (pp. 90-116). Wiesbaden: Westdeutscher Verlag.

Bonikowski, B. (2016). Nationalism in settled times. Annual Review of Sociology, 42(1), 427-449.

Brubaker, R. (1996). Nationalism reframed: Nationhood and the national question in the new Europe. Cambridge: Cambridge University Press.

Bulska, D., \& Winiewski, M. (2018). Antisemitism in Poland. Results of Polish Prejudice Survey 3. Warsaw: Center for Research on Prejudice. http://cbu.psychologia.pl/uploads/PPS3_raporty/Antisemitism_PPS3_DB_MHW_fin.pdf.

Burant, S. R. (1985). The January uprising of 1863 in Poland: Sources of disaffection and the arenas of revolt. European History Quarterly, 15, 131-156.

Calhoun, C. (1997). Nationalism. Minneapolis: Open University Press.

Carling, J. (2014). Scripting remittances: Making sense of money transfers in transnational relationships. International Migration Review, 48(1), 218-262.

Castles, S. (2010). Understanding global migration: A social transformation perspective. Journal of Ethnic and Migration Studies, 36(10), 1565-1586

Codogni, P. (2010). Afrykańczycy w Warszawie w latach 1945-1975 [Africans in Warsaw 1945-1975]. In P. Średziński, \& M. Diouf (Eds.), Afryka w Warszawie. Dzieje afrykańskiej diaspory nad Wisła [Africa in Warsaw. History of African Diaspora at Vistula River] (pp. 114-130). Warszawa: Fundacja Afryka Inaczej.

Coward, M. (2018). Against network thinking: A critique of pathological sovereignty. European Journal of International Relations, 24(2), 440-463.

Danecka, M., \& Jaroszewska, E. (2013). Imigranci z Afryki w Polsce. Przyczynek do analizy czynników blokujących ich napływ i integrację [Immigrants from Africa in Poland. A case study for analysis of factors blocking their inflow and integration]. Kultura i Społeczeństwo [Culture and Society] 57(3), 157-184.

Datta, A., \& Brickell, K. (2009). "We have a little bit more finesse, as a nation": Constructing the polish worker in London's building sites. Antipode, 41(3), 439-464

Dunn, E. C. (2004). Privatizing Poland: Baby food, big business, and the remaking of labor. Ithaca: Cornell University Press.

Durand, J., \& Massey, D. S. (1992). Mexican migration to the USA. Latin American Research Review, 27(2), 3-42.

Eade, J. (2007). Class and ethnicity: Polish migrant workers in London: Full research report. ESRC End of Award report, RES-00022-1294. Swindon: Economic and Social Research Council.

Ehrkamp, P., \& Leitner, H. (2006). Rethinking immigration and citizenship: New spaces of migrant transnationalism and belonging. Environment and Planning A: Economy and Space, 38(9), 1591-1597.

Erel, U. (2010). Migrating cultural capital: Bourdieu in migration studies. Sociology, 44(4), 642-660.

Erickson, M. (2012). Network as metaphor. International Journal of Criminology and Sociological Theory, 5(2), 912-921.

Faist, T. (2012). Toward a transnational methodology: Methods to address methodological nationalism, essentialism, and Positionality. Revue Européenne des Migrations Internationales, 28(1), 51-70.

Foner, N. (2000). From Ellis Island to JFK: New York's two great waves of immigration. New Haven: Yale University Press.

Fouron, G., \& Schiller, N. G. (2001). All in the family: Gender, transnational migration, and the nation-state. Identities, 7(4), 539-582.

Glick Schiller, N. (2005). Long-distance nationalism. In M. Ember (Ed.), Encyclopedia of diasporas: Immigrant and refugee cultures around the world (vol. 193, pp. 570-580). New York: Springer.

Glick Schiller, N. (2006). Introduction. Focaal, 2006(47), 3-17. https://www.berghahnjournals.com/view/journals/focaal/2006/47/ focaal470102.xml. Accessed 17 Mar 2020.

Hannerz, U. (1996). Transnational connections: Culture, people, places. London: Routledge.

Hardy, J. (2009). Poland's new capitalism, (1st ed., ). London: Pluto Press.

Hochschild, A. R. (2016). Strangers in their own land: Anger and mourning on the American right. New York: The New Press.

Holton, R. J. (2005). Network discourses: Proliferation, critique and synthesis. Global Networks, 5, 209-215.

Kastoryano, R. (2006). Vers un nationalisme transnational: Redéfinir la nation, le nationalisme et le territoire [Toward a transnational nationalism: Redefining the nation, nationalism and territory]. Revue Française de Science Politique, 56(4), 533-553.

Krieg, L. J. (2015). 'It's a real Totschlag-argument': The attribution of agency to the holocaust among contemporary young German adults in a discourse of remembering and forgetting. Social Anthropology, 23(3), 314-329.

Lamont, M. (1992). Money, morals, and manners: The culture of the French and American upper-middle class. Chicago and London: The University of Chicago Press.

Lamont, M., \& Fleming, C. M. (2005). Everyday antiracism: Competence and religion in the cultural repertoire of the African American elite. Du Bois Review: Social Science Research on Race, 2(1), 29-43. 
Levitt, P., \& Glick Schiller, N. (2004). Conceptualizing simultaneity: A transnational social field perspective on society. International Migration Review, 38(3), 1002-1039.

Levitt, P., \& Jaworksy, B. N. (2007). Transnational migration studies: Past developments and future trends. Annual Review of Sociology, 33, 129-156.

Levitt, P., \& La Dehesa, R. d. (2017). Rethinking "transnational migration and the re-definition of the state" or what to do about (semi-) permanent impermanence. Ethnic and Racial Studies, 40(9), 1520-1526.

Levy, D., \& Sznaider, N. (2002). Memory unbound. European Journal of Social Theory, 5(1), 87-106.

Massey, D. S., \& España, F. G. (1987). The social process of international migration. Science, 237(4816), 733-738.

Massey, D. S., Goldring, L., \& Durand, J. (1994). Continuities in transnational migration: An analysis of nineteen Mexican communities. American Journal of Sociology, 99(6), 1492-1533.

Mitchell, K. (1997). Transnational discourse: Bringing geography Back in. Antipode, 29(2), 101-114

Nieswand, B. (2018). Border dispositifs and border effects. Exploring the nexus between transnationalism and border studies. Identities, 25(5), 592-609.

Nowicka, M. (2014a). Migrating skills, skilled migrants and migration skills: The influence of contexts on the validation of migrants' skills. Migration Letters, 11(2), 171-186.

Nowicka, M. (2014b). Successful earners and failing others: Transnational orientation as biographical resource in the context of labor migration. International Migration, 52(1), 74-86.

Nowicka, M. (2018a). "I don't mean to sound racist but ... "Transforming racism in transnational Europe. Ethnic and Racial Studies, 41(5), 824-841.

Nowicka, M. (2018b). Cultural Precarity: Migrants' positionalities in the light of current anti-immigrant populism in Europe. Journal of Intercultural Studies, 39(5), 527-542.

Nowicka, M. (2020). 'Uni-Culti' myths and liberal dreams: Brexit and austerity from the perspective of migrants. In M. Guderjan, H. Mackay, \& G. Stedman (Eds.), Contested Britain: Brexit, austerity and agency. Bristol: Policy Press.

Nowicka, M., \& Krzyżowski, Ł. (2017). The social distance of poles to other minorities: A study of four cities in Germany and Britain. Journal of Ethnic and Migration Studies, 43(3), 359-378. 3

Piore, M. J. (1979). Birds of passage: Migrant labor and industrial societies. Cambridge: Cambridge University Press.

Plonowska Ziarek, E. (2007). Melancholic nationalism and the pathologies of commemorating the Holocaust in Poland. In D. Glowacka, \& J. Zylinska (Eds.), Imaginary neighbors: Mediating Polish-Jewish relations after the Holocaust (pp. 303-326). Lincoln: University of Nebraska Press.

Portes, A. (Ed.) (1995). The economic sociology of immigration: Essays on networks, ethnicity, and entrepreneurship. New York: Russel Sage Foundation.

Portes, A., Guarnizo, L. E., \& Landolt, P. (1999). The study of transnationalism: Pitfalls and promise of an emergent research field. Ethnic and Racial Studies, 22(2), 217-237.

Robertson, R. (1995). Glocalization: Time-space and homogeneity-heterogeneity. In M. Featherstone, S. Lash, \& R. Robertson (Eds.), Global Modernities (pp. 25-44). London: Sage.

Roudometof, V. (2005). Transnationalism, cosmopolitanism and Glocalization. Current Sociology, 53(1), 113-135.

Smith, M. P., \& Guarnizo, L. (Eds.) (1998). Transnationalism from below. New Brunswick: Transaction Publishers.

Thomas, W., \& Znaniecki, F. (1984 [1918-1920]). The polish peasant in Europe and America (edited by E. Zaretsky). Urbana: University of Illinois Press.

Tsing, A. L. (2005). Friction: An ethnography of global connection. Princeton: Princeton University Press.

Waldinger, R. (2015). The cross-border connection: Immigrants, emigrants, and their homelands. Cambridge: Harvard University Press.

Werbner, P. (2015). Introduction: The Dialectics of Cultural Hybridity. In P. Werbner, \& T. Modood (Eds.), Debating Cultural Hybridity: Multicultural Identities and the Politics of Anti-Racism - New Edition (pp. 27-51). London: Zed Books.

Wimmer, A., \& Glick Schiller, N. (2002). Methodological nationalism and beyond: Nation-state building, migration and the social sciences. Global Networks, 2(4), 301-334.

Ząbek, M. (2007). Biali i czarni: Postawy Polaków wobec Afryki i Afrykanów [Whites and Blacks: Attitudes of Poles towards Africa and Africans]. Warszawa: DiG.

\section{Publisher's Note}

Springer Nature remains neutral with regard to jurisdictional claims in published maps and institutional affiliations.

\section{Submit your manuscript to a SpringerOpen ${ }^{\circ}$ journal and benefit from:}

- Convenient online submission

- Rigorous peer review

- Open access: articles freely available online

- High visibility within the field

- Retaining the copyright to your article

Submit your next manuscript at $>$ springeropen.com 